\title{
POTENSI OLIGOCHITOSAN, VITAZYME DAN BIOFERTILIZER DALAM MENINGKATKAN PERTUMBUHAN DAN PRODUKSI PADI (Oryza sativa L.)
}

\section{The Potential of Oligochitosan, Vitazyme and Biofertilizer to Improve Growth and Yield of Rice (Oryza sativa L.)}

\author{
Anas Iswandi1)*, Fahrizal Hazra1), dan Velicia Desyana Rakhmadina ${ }^{2)}$ \\ 1) Departemen Ilmu Tanah dan Sumberdaya Lahan, Fakultas Pertanian, IPB, J1. Meranti Kampus IPB Darmaga, \\ Bogor 16680 \\ 2) Alumni Program Studi Manajemen Sumberdaya Lahan Fakultas Pertanian IPB, J1. Meranti Kampus IPB \\ Darmaga, Bogor 16680
}

\begin{abstract}
Oligochitosan, Vitazyme and Biofertilizer have been reported to increase growth and yield several crops. The objective of this study was to evaluate the ability of Oligochitosan, Vitazyme, and Biofertilizer to improve growth and yield of rice. This study consisted of pot and field experiments. The experimental design applied was the randomized block design with four replicates. The treatments used in pot experiment were application of $100 \%$ dosage NPK fertilizer, application of 50\% dosage NPK fertilizer in combination with Oligochitosan (Japan and BATAN-Indonesian Nuclear Energy Agency), Biofertilizer Azozo, and Vitazyme. The treatments for field experiment were limited to application of $100 \%$ dosage of NPK fertilize, 50\% dosage of NPK fertilizer in combination with Oligochitosan (Japan) or Biofertilizer. Results of this experiments showed that in the pot experiment, application 100\% NPK dosage, significantly increased growth and yield of rice compared to the treatment of $50 \%$ NPK dosage. Application of 50\% NPK fertilizer dosage in combination with Oligochitosan or Vitazyme or Biofertilizer, significantly increased growth and yield of rice compared to application of 50\% NPK dosage only. Moreover application of 50\% NPK fertilizer dosage in combination with Oligochitosan or Vitazyme or Biofertilizer, had the same or even higher yield than the yield of the treatment with 100\% NPK fertilizer. So, that application of Oligochitosan or Vitazyme or Biofertilizer in combination with application of 50\% NPK reduced NPK requirement by 50\%. However, in the field experiments, we did not find the significant difference of growth and yield of rice treated with $100 \%$ NPK fertilizer dosage with 50\% NPK fertilizer dosage. Hence we could not evaluate the effect of combination between Oligochitosan or Biofertilizer application and 50\% NPK fertilizer dosage on growth and yield of rice compared to application of 100\% NPK fertilizer dosage.
\end{abstract}

Keywords: Biofertilizer, growth and yield of rice, Oligochitosan, Vitazyme

\begin{abstract}
ABSTRAK
Penggunaan Oligochitosan, Vitazyme, dan Biofertilizer dapat menjadi salah satu alternatif dalam upaya meningkatkan pertumbuhan dan produksi. Penelitian ini bertujuan untuk mengevaluasi kemampuan Oligochitosan, Vitazyme, dan Biofertilizer dalam meningkatkan pertumbuhan dan produksi padi. Penelitian ini terdiri atas penelitian menggunakan media tanah dalam pot di lapangan dan penelitian di lahan sawah. Penelitian dirancang dengan menggunakan Rancangan Acak Kelompok dengan empat ulangan. Perlakuan pada penelitian pot terdiri atas pemberian pupuk NPK, Oligochitosan Jepang, Oligochitosan BATAN, Biofertilizer Azozo, dan Vitazyme, sementara penelitian lapang perlakuan hanya menggunakan pupuk NPK, Oligochitosan Jepang, dan Biofertilizer Azozo. Hasil penelitian menunjukkan bahwa pemberian pupuk NPK $100 \%$ nyata meningkatkan pertumbuhan dan produksi padi dibandingkan dengan pemupukan NPK 50\%. Kombinasi perlakuan pupuk NPK $50 \%$ dengan Oligochitosan, Vitazyme, atau Biofertilizer, nyata meningkatkan produksi padi menyamai atau melebihi pemupukan NPK 100\%. Ini berarti bahwa baik Oligochitosan, Vitazyme atau Biofertilizer bila dikombinasikan dengan pemberian 50\% NPK mampu menggantikan 50\% pupuk NPK. Akan tetapi pada penelitian di lahan sawah, tidak adanya perbedaan pertumbuhan maupun produksi padi yang diberi perlakuan NPK 100\% dengan perlakuan NPK 50\%, sehingga dampak pemberian Oligochitosan, Vitazyme atau Biofertilizer yang dikombinasikan dengan pemberian 50\% NPK tidak dapat dievaluasi.
\end{abstract}

Kata kunci: Biofertilizer, pertumbuhan dan produksi padi, Oligochitosan, Vitazyme 


\section{PENDAHULUAN}

Peningkatan permintaan beras setiap tahunnya mendorong pemerintah menggagas program Peningkatan Produksi Beras Nasional (P2BN). Salah satu bentuk penerapan program $\mathrm{P} 2 \mathrm{BN}$ adalah melalui peningkatan produktivitas pertanian, khususnya teknologi pemupukan. Penerapan teknologi pemupukan hingga saat ini hanya terbatas dalam bentuk subsidi pupuk.

Alokasi anggaran subsidi pupuk terus mengalami peningkatan dari tahun ke tahun. Pemberian subsidi pupuk yang terus meningkat mendorong penggunaan pupuk anorganik yang semakin tinggi. Hal ini menimbulkan fenomena leveling off, sehingga pemupukan menjadi tidak efisien dan efektif dalam mencapai peningkatan hasil pertanian. Ancaman penurunan kualitas fisik, kimia, dan biologi tanah akibat ketidakseimbangan penggunaan pupuk anorganik dengan pupuk organik serta kerusakan lingkungan juga merupakan dampak dari penggunaan pupuk anorganik yang tidak tepat.

Fenomena leveling off yang dihadapi pertanian Indonesia mencerminkan bahwa teknologi pemupukan yang dilaksanakan belum cukup dalam mencapai efisiensi produksi. Hal ini telah memberikan suatu gagasan dalam menggunakan berbagai senyawa yang dapat mengurangi penggunaan pupuk buatan. Senyawa tersebut antara lain berupa Oligochitosan, Vitazyme, dan Biofertilizer sebagai bentuk inovasi teknologi pemupukan. Oligochitosan dan Vitazyme dapat mengurangi takaran pupuk untuk tanaman. Pemberian Oligochitosan dan Vitazyme dapat memperbaiki proses fisiologis tanaman agar adaptif dalam mempergunakan hara yang tersedia di dalam tanah. Oligochitosan merupakan chitosan yang di-iradiasi dengan sinar gamma dari Co-60 dan kaya akan asam amino serta plant growth promoter seperti IAA, giberelin dan sitokinin (El-Tahany et al., 2012). Vitazyme adalah biostimulan alami yang mengandung aktivator hayati dan bahan aktif berupa enzim, vitamin, brasinosteroid dan triakontanol (Syltie, 1998). Biofertilizer merupakan inokulan mikrob tanah yang menguntungkan pertumbuhan tanaman melalui berbagai mekanisme seperti peningkatan penyerapan hara, peningkatan kelarutan hara, dan menghambat perkembangan patogen serta meningkatkan ketahanan tanaman terhadap serangan penyakit. Penelitian ini bertujuan untuk mengevaluasi kemampuan Oligochitosan, Vitazyme, dan Biofertilizer dalam meningkatkan pertumbuhan dan produksi padi.

\section{BAHAN DAN METODE}

Lokasi penelitian dilaksanakan di dua tempat. Lokasi pertama bertempat di Desa Cihideung Udik, Kecamatan Ciampea, Kabupaten Bogor, berupa penelitian pot dan penelitian lapang. Lokasi kedua berada di Desa Situ Gede, Kecamatan Bogor Barat, Kota Bogor berupa penelitian lapang. Karakteristik tanah yang digunakan dalam penelitian disajikan pada Tabel 1 dan Tabel 2 .

Bahan yang digunakan adalah padi varietas Ciherang, pupuk anorganik berupa Urea, SP-36, KCl, Oligochitosan BATAN (Tabel 3), Oligochitosan Jepang, Biofertilizer Azozo (Tabel 4), dan Vitazyme (Tabel 5). Media untuk memperbanyak dan menghitung populasi mikrob adalah NB (Nutrient Broth), NFM (Nitrogen Free
Mannitol), NFB (Nitrogen Free Bromhtymol), Pikovskaya dan PDA (Potato Dextrose Agar).

Tabel 1. Sifat kimia tanah yang digunakan dalam penelitian di Desa Cihideung Udik, Kecamatan Ciampea, Bogor

\begin{tabular}{|c|c|c|c|}
\hline Parameter & Metode & Satuan & Nilai \\
\hline $\mathrm{pH} \mathrm{H}_{2} \mathrm{O}(1: 5)$ & - & - & 5.40 \\
\hline $\mathrm{pH} \mathrm{KCl} \mathrm{(1:5)}$ & - & - & 4.30 \\
\hline C-organik & Walkley \& Black & $\%$ & 1.54 \\
\hline P-total & $\mathrm{HCl} 25 \%$ & $\mathrm{mg} \mathrm{kg}^{-1}$ & 44.6 \\
\hline K-total & $\mathrm{HCl} 25 \%$ & $\mathrm{mg} \mathrm{kg}^{-1}$ & 83.0 \\
\hline Si-tersedia & Buffer Asam Asetat & $\mathrm{mg} \mathrm{kg}^{-1}$ & 19.1 \\
\hline $\mathrm{NH}_{4}$ & $1 \mathrm{~N} \mathrm{KCl}$ & $\mathrm{mg} \mathrm{kg}^{-1}$ & 57.9 \\
\hline $\mathrm{NO}_{3}$ & $0.01 \mathrm{M} \mathrm{CaCl}$ & $\mathrm{mg} \mathrm{kg}^{-1}$ & 15.2 \\
\hline Fe-tersedia & $0.05 N \mathrm{HCl}$ & $\mathrm{mg} \mathrm{kg}^{-1}$ & 7.40 \\
\hline
\end{tabular}

Tabel 2. Sifat kimia dan fisik tanah yang digunakan dalam penelitian di Desa Situ Gede, Kecamatan Bogor Barat, Kota Bogor

\begin{tabular}{|c|c|c|c|c|}
\hline Parameter & Metode & Satuan & \multicolumn{2}{|c|}{ Hasil } \\
\hline $\mathrm{pH}$ & $\mathrm{H}_{2} \mathrm{O}(1: 1)$ & - & & 5.70 \\
\hline C-organik & Walkley \& Black & $\%$ & & 1.68 \\
\hline N-total & Kjeldahl & $\%$ & & 0.15 \\
\hline P-tersedia & Bray I & $\mathrm{mg} \mathrm{kg}^{-1}$ & & 5.8 \\
\hline $\mathrm{Ca}_{\mathrm{dd}}$ & $N \mathrm{NH}_{4} \mathrm{OAc} \mathrm{pH} 7.0$ & $\mathrm{C} \mathrm{mol} \mathrm{kg}{ }^{-1}$ & & 10.8 \\
\hline $\mathrm{Mg}_{\mathrm{dd}}$ & $N \mathrm{NH}_{4} \mathrm{OAc} \mathrm{pH} 7.0$ & $\mathrm{C} \mathrm{mol} \mathrm{kg}{ }^{-1}$ & & 3.35 \\
\hline $\mathrm{K}_{\mathrm{dd}}$ & $N \mathrm{NH}_{4} \mathrm{OAc} \mathrm{pH} 7.0$ & $\mathrm{C} \mathrm{mol} \mathrm{kg}{ }^{-1}$ & & 0.35 \\
\hline $\mathrm{Na}_{\mathrm{dd}}$ & $N \mathrm{NH}_{4} \mathrm{OAc}$ pH 7.0 & $\mathrm{C} \mathrm{mol} \mathrm{kg}{ }^{-1}$ & & 0.94 \\
\hline KTK & $N \mathrm{NH}_{4} \mathrm{OAc} \mathrm{pH} 7.0$ & $\mathrm{C} \mathrm{mol} \mathrm{kg}{ }^{-1}$ & & 19.4 \\
\hline $\mathrm{KB}$ & Jumlah Basa-Basa & $\%$ & & 79.8 \\
\hline$A l_{d d}$ & $N \mathrm{KCl}$ & $\mathrm{C} \mathrm{mol} \mathrm{kg}{ }^{-1}$ & & $\operatorname{tr}$ \\
\hline $\mathrm{H}_{\mathrm{dd}}$ & $N \mathrm{KCl}$ & $\mathrm{C} \mathrm{mol} \mathrm{kg}{ }^{-1}$ & & 0.20 \\
\hline Fe-tersedia & $0.05 \mathrm{~N} \mathrm{HCl}$ & $\mathrm{mg} \mathrm{kg}^{-1}$ & & 7.33 \\
\hline $\mathrm{Cu}$-tersedia & $0.05 \mathrm{~N} \mathrm{HCl}$ & $\mathrm{mg} \mathrm{kg}^{-1}$ & & 1.22 \\
\hline Zn-tersedia & $0.05 \mathrm{~N} \mathrm{HCl}$ & $\mathrm{mg} \mathrm{kg}^{-1}$ & & 6.19 \\
\hline \multirow[t]{2}{*}{ Mn-tersedia } & $0.05 \mathrm{~N} \mathrm{HCl}$ & $\mathrm{mg} \mathrm{kg}^{-1}$ & & 155.1 \\
\hline & Penyaringan & $\%$ & Pasir & 10.1 \\
\hline \multirow[t]{2}{*}{ Tekstur } & Pipet & $\%$ & Debu & 38.8 \\
\hline & Pipet & $\%$ & Liat & 51.2 \\
\hline
\end{tabular}

Keterangan: $\operatorname{tr}=$ tidak terukur; $\mathrm{dd}=$ dapat dipertukarkan

Tabel 3. Spesifikasi Oligochitosan yang diproduksi oleh Badan Tenaga Atom Nasional (BATAN)

\begin{tabular}{ll}
\hline Bahan Baku & Limbah kulit udang \\
Pengekstrak & $\mathrm{NaOH}, \mathrm{HCl}$ \\
Derajat Deasetilasi & $85 \%$ \\
Bobot Molekul Rata-Rata & $7-14$ Dalton \\
Sumber Iradiasi & $\mathrm{Co}-60$ \\
Dosis Iradiasi & $75 \mathrm{kGy}$ \\
\hline
\end{tabular}

Tabel 4. Kepadatan mikrob dalam Biofertilizer Azozo yang digunakan pada penelitian di Desa Cihideung Udik dan Desa Situ Gede

\begin{tabular}{ccc}
\hline Jenis Mikrob & $\begin{array}{c}\text { Desa Cihideung } \\
\text { Udik }\end{array}$ & $\begin{array}{c}\text { Desa Situ } \\
\text { Gede }\end{array}$ \\
\hline & $\ldots \ldots\left(\mathrm{SPK} \mathrm{g}^{-1} \mathrm{BKM}\right) \ldots \ldots$ \\
Azotobacter & $4.38 \times 10^{8}$ & $1.84 \times 10^{9}$ \\
Azospirillum & $4.00 \times 10^{7}$ & $1.10 \times 10^{7}$ \\
Mikrob Pelarut Fosfat & $8.27 \times 10^{8}$ & $2.09 \times 10^{9}$ \\
\hline
\end{tabular}

Penelitian pot di Desa Cihideung Udik menggunakan tujuh perlakuan dengan empat ulangan serta menggunakan Rancangan Acak Lengkap. Perlakuan tersebut adalah (1) NPK $100 \%$, (2) NPK 50\%, (3) NPK $50 \%+$ Oligochitosan Jepang, (4) NPK 50\% + Biofertilizer Azozo, (5) NPK 50\% + Oligochitosan Jepang + Biofertilizer Azozo, (6) NPK 50\% + Oligochitosan BATAN, dan (7) NPK 50\% + Vitazyme. Penelitian pot 
menggunakan pupuk dasar dengan dosis $200 \mathrm{mg} \mathrm{N} \mathrm{kg}^{-1}$, $100 \mathrm{mg} \mathrm{P} \mathrm{kg}{ }^{-1}$, dan $100 \mathrm{mg} \mathrm{K} \mathrm{kg}{ }^{-1}$ untuk 100\% NPK. Pot diisi tanah seberat $10 \mathrm{~kg}$ tanah kering mutlak untuk setiap pot.

Penelitian di lapang menggunakan Rancangan Acak Kelompok (RAK) faktor tunggal dengan empat ulangan. Dosis pupuk didasarkan pada takaran yang umum digunakan petani di sekitar lokasi penelitian, yaitu $300 \mathrm{~kg}$ Urea ha ${ }^{-1}, 150 \mathrm{~kg} \mathrm{SP}-36 \mathrm{ha}^{-1}$, dan $200 \mathrm{~kg} \mathrm{KCl} \mathrm{ha}{ }^{-1}$, sementara di Desa Situ Gede menggunakan dosis $150 \mathrm{~kg}$ Urea ha $^{-1}, 100 \mathrm{~kg} \mathrm{SP}-36 \mathrm{ha}^{-1}$, dan $100 \mathrm{~kg} \mathrm{KCl} \mathrm{ha}^{-1}$ untuk perlakuan $100 \%$ NPK. Empat perlakuan yang diterapkan adalah : (1) NPK 100\%, (2) NPK 50\%, (3) NPK 50\% + Oligochitosan Jepang, (4) NPK 50\% + Biofertilizer Azozo. Hal ini didasarkan pada pertimbangan ketersediaan lahan percobaan dan biaya penelitian serta volume pekerjaan.

Analisis statistik untuk mengevaluasi pengaruh perlakuan menggunakan uji ANOVA dan dilanjutkan dengan menggunakan uji Duncan dengan selang kepercayaan $95 \%(\alpha=5 \%)$.

Tabel 5. Kandungan senyawa dan unsur mikro dalam Vitazyme (Syltie, 1998)

\begin{tabular}{lcc}
\hline \multicolumn{1}{c}{ Parameter } & Satuan & Hasil \\
\hline Brasinosteroid & $\mathrm{mg} \mathrm{ml}^{-1}$ & 0.022 \\
1-triakontanol & $\mathrm{mg} \mathrm{ml}^{-1}$ & 0.33 \\
Giberelin & $\mathrm{mg} \mathrm{ml}^{-1}$ & 0.13 \\
Kinetin & $\mathrm{mg} \mathrm{l} \mathrm{ml}^{-1}$ & $<1$ \\
IAA & $\mathrm{mg} \mathrm{ml}^{-1}$ & $<1$ \\
Biotin & $\mathrm{mg} \mathrm{lb}^{-1}$ & 0.006 \\
Asam folat & $\mathrm{mg} \mathrm{lb}^{-1}$ & 0.007 \\
Niasin & $\mathrm{mg} \mathrm{lb}^{-1}$ & 0.077 \\
Asam pantotenat & $\mathrm{mg} \mathrm{lb}^{-1}$ & 0.13 \\
Vitamin B1 (thiamin) & $\mathrm{mg} \mathrm{lb}^{-1}$ & 2.03 \\
Vitamin B2 (riboflavin) & $\mathrm{mg} \mathrm{lb}^{-1}$ & 0.078 \\
Vitamin B6 (piridoksin) & $\mathrm{mg} \mathrm{lb}^{-1}$ & 1.2 \\
Vitamin B12 (kobalamin) & $\mathrm{mg} \mathrm{lb}^{-1}$ & 0.0015 \\
Mn & $\mathrm{mg} \mathrm{kg}^{-1}$ & 3065 \\
Cu & $\mathrm{mg} \mathrm{kg}^{-1}$ & 2673 \\
Zn & $\mathrm{mg} \mathrm{kg}^{-1}$ & 3192 \\
B & $\mathrm{mg} \mathrm{kg}^{-1}$ & 217 \\
Mo & $\mathrm{mg} \mathrm{kg}^{-1}$ & 6 \\
\hline
\end{tabular}

\section{Pelaksanaan Penelitian}

\section{Penelitian Pot}

Penelitian diawali dengan membuat Biofertilizer Azozo melalui perbanyakan isolat di dalam media cair Nutrient Broth untuk Azospirillum, Azotobacter (TT 58), dan bakteri pelarut fosfat (BPF 9). Fungi pelarut fosfat (FPF 4) diperbanyak pada media Pikovskaya cair. Fungi pelarut fosfat (FPF 4) yang telah tumbuh pada media Pikovskaya cair dipindahkan ke dalam media Potato Dextrose Agar (PDA) untuk diambil sporanya dengan menggunakan larutan fisiologis. Spora fungi pelarut fosfat dan media Nutrient Broth yang mengandung isolat lainnya dicampurkan pada bahan pembawa (carrier) berupa arang batok kelapa dan tanah steril. Media tanam untuk penelitian pot berasal dari lahan penelitian lapang di Desa Cihideung Udik. Tanah yang digunakan adalah sebanyak $10 \mathrm{~kg}$ untuk setiap pot (BKM). Pemberian Oligochitosan dan Vitazyme pada penelitian pot menggunakan volume semprot $6.6 \mathrm{ml} \mathrm{rumpun}^{-1}$. Pemeliharaan tanaman dilakukan dengan penyiangan gulma dan penyemprotan pestisida nabati untuk mengendalikan serangan hama dan penyakit.

Pengukuran variabel pertumbuhan dilaksanakan melalui pengamatan parameter tinggi tanaman dan jumlah anakan setiap dua minggu. Variabel produksi yang diamati meliputi jumlah anakan produktif, bobot gabah kering panen (GKP), bobot gabah kering giling (GKG), bobot gabah isi, dan presentase gabah hampa.

\section{Penelitian Lapang}

Persiapan lahan untuk penelitian lapang meliputi pengolahan tanah berupa pembajakan dan pembalik tanah, pelumpuran, serta pembuatan petak penelitian. Penelitian lapang di Desa Cihideung Udik menggunakan petak berukuran $4 \mathrm{~m}$ x $5 \mathrm{~m}$, sementara di Desa Situ Gede berukuran $5 \mathrm{~m} \times 6 \mathrm{~m}$.

Penanaman bibit pada penelitian di Desa Cihideung Udik menggunakan bibit berumur 10 hari, dengan sistem budidaya System of Rice Intensification (SRI) dan menggunakan 1 bibit untuk setiap lubang tanam. Penelitian di Desa Situ Gede menggunakan bibit berumur 15 hari, sistem budidaya konvensional, dan menanam tiga bibit per lubang tanam. Hal ini disebabkan karena serangan keong mas yang sangat berat di Desa Situ Gede, sehingga sistem budidaya SRI dikhawatirkan mengalami kendala kalau diterapkan. Jarak tanam yang digunakan untuk kedua penelitian lapang adalah $25 \mathrm{~cm}$ x $25 \mathrm{~cm}$. Pemakaian Biofertilizer Azozo dilaksanakan dengan mencelupkan akar bibit padi ke dalam biakan mikrob sesaat sebelum penanaman dilakukan.

Pemupukan menggunakan pupuk anorganik SP36 dilaksanakan sekali saat tanam. Pupuk Urea dan $\mathrm{KCl}$ diberikan dalam dua tahap, yaitu saat tanam dan lima minggu setelah tanam. Pemberian Oligochitosan dan Vitazyme pada penelitian lapang menggunakan volume semprot 400 liter $\mathrm{ha}^{-1}$. Pemberian Oligochitosan dan Vitazyme di Desa Cihideung Udik dilaksanakan saat perendaman benih (10 ppm Oligochitosan; 5\% Vitazyme), 4 MST (20 ppm Oligochitosan; 1\% Vitazyme), dan 8 MST (30 ppm Oligochitosan; 1\% Vitazyme). Pemberian Oligochitosan di Desa Situ Gede juga dilakukan ketika perendaman benih $\left(10 \mathrm{mg} \mathrm{kg}^{-1}\right), 4$ dan $8 \mathrm{MST}$ dengan konsentrasi $100 \mathrm{mg} \mathrm{kg}^{-1}$. Pemeliharaan tanaman dilakukan dengan penyiangan gulma dan penyemprotan pestisida nabati untuk mengendalikan serangan hama dan penyakit.

Pengukuran variabel pertumbuhan dilaksanakan melalui pengamatan parameter tinggi tanaman dan jumlah anakan. Tinggi tanaman dan jumlah anakan diamati setiap dua minggu pada penelitian di Desa Cihideung Udik, sementara di Desa Situ Gede diamati setiap empat minggu sekali. Variabel produksi yang diamati di Desa Cihideung Udik meliputi: jumlah anakan produktif, bobot gabah kering panen (GKP), bobot gabah kering giling (GKG), bobot gabah isi, dan presentase gabah hampa. Pengamatan komponen hasil dan variabel produksi di Desa Situ Gede terdiri atas: jumlah anakan produktif, panjang malai, jumlah gabah per malai, jumlah gabah isi, jumlah gabah hampa, bobot GKP, bobot GKG, bobot gabah isi, dan presentase gabah hampa. 


\section{HASIL DAN PEMBAHASAN}

\section{Penelitian Pot}

\section{Pertumbuhan Padi}

Hasil analisis terhadap tinggi tanaman padi (Tabel 6) menunjukkan bahwa aplikasi Oligochitosan, Vitazyme, dan Biofertilizer tidak berpengaruh nyata terhadap tinggi tanaman pada umur 2, 4, dan 8 MST. Akan tetapi pada umur 6 MST, perlakuan kombinasi Oligochitosan, Vitazyme, dan Biofertilizer dengan NPK 50\% nyata lebih tinggi dibandingkan dengan tinggi tanaman yang hanya mendapat perlakuan 50\% NPK saja. Tinggi tanaman pada perlakuan kombinasi 50\% NPK dengan Oligochitosan, Vitazyme maupun Biofertilizer sama tingginya dengan padi yang mendapatkan perlakuan $100 \%$ NPK.

Tabel 6. Pengaruh Oligochitosan, Vitazyme, dan Biofertilizer terhadap tinggi padi umur 2-8 MST pada percobaan pot

\begin{tabular}{|c|c|c|c|c|}
\hline \multirow{2}{*}{ Perlakuan } & \multicolumn{4}{|c|}{ Tinggi Tanaman } \\
\hline & 2 MST & $4 \mathrm{MST}$ & $6 \mathrm{MST}$ & $8 \mathrm{MST}$ \\
\hline & \multicolumn{4}{|c|}{$\ldots \ldots \ldots \ldots \ldots, \ldots \ldots$} \\
\hline NPK $50 \%$ & 30.73 & 58.28 & $74.80 \mathrm{~b}$ & 88.28 \\
\hline NPK $50 \%+$ Oligochitosan $(\mathrm{J})$ & 31.70 & 60.15 & $81.53 \mathrm{a}$ & 95.20 \\
\hline NPK $50 \%$ + Biofertilizer (A) & 29.80 & 57.18 & $80.68 \mathrm{ab}$ & 85.23 \\
\hline NPK $50 \%$ + Vitazyme & 33.03 & 57.45 & $79.78 \mathrm{ab}$ & 93.00 \\
\hline
\end{tabular}

Perlakuan kombinasi $50 \%$ NPK dengan Oligochitosan, Vitazyme, dan Biofertilizer berpengaruh nyata terhadap jumlah anakan per rumpun padi umur 6 dan 8 MST dan umumnya tidak berbeda dengan perlakuan $100 \%$ NPK dan berbeda sangat nyata dibandingkan dengan perlakuan NPK $50 \%$ saja (Tabel 7). Hasil penelitian ini menunjukkan bahwa pemberian Oligochitosan, Vitazyme atau Biofertilizer membantu tanaman untuk mengambil unsur hara sehingga memperbaiki pertumbuhan tanaman padi dan menyamai pertumbuhan tanaman padi yang mendapatkan pupuk NPK $100 \%$.

Tabel 7. Pengaruh Oligochitosan, Vitazyme, dan Biofertilizer terhadap jumlah anakan padi per rumpun pada umur 2-8 MST pada percobaan pot

\begin{tabular}{|c|c|c|c|c|}
\hline \multirow{2}{*}{ Perlakuan } & \multicolumn{4}{|c|}{ Jumlah Anakan } \\
\hline & 2 MST & 4 MST & $6 \mathrm{MST}$ & $8 \mathrm{MST}$ \\
\hline & \multicolumn{4}{|c|}{$\ldots \ldots \ldots \ldots$ anakan rumpun ${ }^{-1} \ldots \ldots \ldots$} \\
\hline NPK $100 \%$ & $4.25 \mathrm{a}$ & $18.00 \mathrm{a}$ & $32.25 \mathrm{a}$ & $32.25 \mathrm{a}$ \\
\hline NPK $50 \%$ & $1.75 b$ & $14.00 \mathrm{ab}$ & $16.75 \mathrm{c}$ & $14.50 \mathrm{c}$ \\
\hline NPK $50 \%+$ Oligochitosan $(\mathrm{J})$ & $2.25 b$ & $14.75 \mathrm{ab}$ & $26.00 \mathrm{ab}$ & $22.50 \mathrm{~b}$ \\
\hline NPK $50 \%$ + Biofertilizer (A) & $2.50 \mathrm{~b}$ & $13.50 \mathrm{ab}$ & $23.75 \mathrm{ab}$ & $20.50 b$ \\
\hline NPK $50 \%+$ Oligochitosan $(\mathrm{J})+$ Biofertilizer (A) & $2.00 \mathrm{~b}$ & $11.33 b$ & $22.33 \mathrm{ab}$ & $22.67 b$ \\
\hline NPK 50\% + Oligochitosan (B) & $2.00 \mathrm{~b}$ & $13.00 \mathrm{ab}$ & $21.75 b$ & $21.00 \mathrm{~b}$ \\
\hline NPK $50 \%+$ Vitazyme & $3.00 \mathrm{ab}$ & $17.25 \mathrm{ab}$ & $30.75 \mathrm{ab}$ & $28.00 \mathrm{ab}$ \\
\hline
\end{tabular}

Keterangan: Angka yang diikuti oleh huruf yang sama pada kolom yang sama tidak berbeda nyata pada taraf 0.05 berdasarkan uji Duncan

Pengamatan hasil padi memperlihatkan bahwa perlakuan kombinasi antara NPK $50 \%$ dengan Oligochitosan, Vitazyme, dan Biofertilizer nyata lebih tinggi dari pada perlakuan $50 \%$ NPK saja dan menyamai produksi padi pada perlakuan $100 \%$ NPK. (Tabel 8). Dengan kata lain bahwa pemberian Oligochitosan, Vitazyme, dan Biofertilizer mengurangi jumlah pupuk NPK yang dibutuhkan tanaman.

Peningkatan pertumbuhan dan produksi padi pada penelitian pot disebabkan oleh peranan Oligochitosan, Vitazyme, dan Biofertilizer yang berperanan dalam perbaikan metabolisme tanaman. Oligochitosan merupakan salah satu bentuk polisakarida yang berfungsi sebagai sinyal biologis di dalam sel dan mampu mengatur mekanisme pertahanan, simbiosis, serta proses perkembangan tumbuhan (Dzung, 2010). Oligochitosan juga mengandung plant growth promoter berupa giberelin, IAA, dan zeatin (Rekso, 2005). Menurut Mawgoud et al. (2010) Oligochitosan diketahui dapat meningkatkan jumlah daun, kandungan klorofil dan ketersediaan asam amino bagi tanaman. Dilain pihak, brasinosteroid yang dikandung oleh Vitazyme adalah salah satu jenis plant growth promoter yang dapat meningkatkan fotosintesis, toleransi tanaman terhadap stres, pembentukan protein serta asam nukleat, dan resistensi terhadap penyakit. Selain brasinosteroid, Vitazyme juga mengandung triakontanol dan porfirin. Triakontanol bermanfaat dalam meningkatkan fiksasi $\mathrm{CO}_{2}$ oleh tanaman, sementara itu porfirin dapat meningkatkan kandungan klorofil pada daun (Syltie, 1998).

Biofertilizer yang diaplikasikan mengandung mikrob penambat nitrogen berupa Azotobacter dan Azospirillum serta mikrob pelarut fosfat. Menurut Nasahi (2010), Azotobacter mampu menghasilkan nitrogen sampai $10 \mathrm{~kg} \mathrm{ha}{ }^{-1}$, sementara Azospirillum dilaporkan dapat memacu peningkatan hasil pertanian antara $30 \%$ sampai $50 \%$. Azotobacter mampu menghasilkan berbagai jenis plant growth promoter, seperti : IAA, giberelin, dan sitokinin. Asam patotenik, tiamin, niasin, dan IAA yang dihasilkan oleh Azospirillum dapat meningkatkan jumlah bulu akar dan akar lateral sehingga meningkatkan penyerapan air dan hara dari tanah, dan pada akhirnya 
peningkatan kualitas dan hasil panen dapat dicapai (Kannan dan Ponmurugan, 2010).

Sementara itu, mikrob pelarut fosfat mampu mengeluarkan berbagai macam asam organik yang dapat membentuk khelat organik (kompleks stabil) dengan kation $\mathrm{Al}, \mathrm{Fe}$ atau $\mathrm{Ca}$ yang mengikat $\mathrm{P}$ sehingga ion
$\mathrm{H}_{2} \mathrm{PO}_{4}^{-}$menjadi terbebas dari ikatannya dan tersedia bagi tanaman. Mikrob pelarut fosfat juga dapat memproduksi auksin, giberelin, dan vitamin dalam menunjang pertumbuhan tanaman (Brahmaprakash dan Pramod, 2012).

Tabel 8. Pengaruh Oligochitosan dan Biofertilizer terhadap jumlah anakan produktif dan variabel produksi padi pada penelitian pot di Desa Cihideung Udik, Kecamatan Ciampea Bogor

\begin{tabular}{|c|c|c|c|c|c|}
\hline Perlakuan & Jumlah Anakan Produktif & Bobot GKP & Bobot GKG & $\begin{array}{l}\text { Bobot Gabah } \\
\text { Isi }\end{array}$ & $\begin{array}{c}\text { Presentase } \\
\text { Gabah Hampa }\end{array}$ \\
\hline & anakan rumpun $^{-1}$ & $\ldots \ldots$ & gram rumpun $^{-1}$ & & $\ldots \% \ldots$ \\
\hline NPK $100 \%$ & $28.25 \mathrm{a}$ & $51.25 \mathrm{a}$ & $46.25 \mathrm{a}$ & $38.68 \mathrm{a}$ & 16.37 \\
\hline NPK $50 \%$ & $12.50 \mathrm{~d}$ & $24.61 b$ & $20.32 b$ & $14.97 \mathrm{~b}$ & 26.38 \\
\hline NPK $50 \%+$ Oligochitosan $(\mathrm{J})$ & $19.75 b c$ & $44.48 \mathrm{a}$ & $40.13 \mathrm{a}$ & $36.12 \mathrm{a}$ & 9.99 \\
\hline NPK $50 \%+$ Biofertilizer (A) & $15.75 \mathrm{~cd}$ & $41.48 \mathrm{a}$ & $37.50 \mathrm{ab}$ & $31.00 \mathrm{a}$ & 17.33 \\
\hline $\begin{aligned} \text { NPK } 50 \% & + \text { Oligochitosan }(\mathrm{J}) \\
& + \text { Biofertilizer }(\mathrm{A})\end{aligned}$ & $18.00 \mathrm{bcd}$ & $41.68 \mathrm{a}$ & $36.43 \mathrm{ab}$ & $32.29 \mathrm{a}$ & 11.34 \\
\hline NPK $50 \%$ + Oligochitosan (B) & $18.50 \mathrm{bcd}$ & $39.47 \mathrm{a}$ & $35.02 \mathrm{ab}$ & $30.82 \mathrm{a}$ & 11.99 \\
\hline NPK $50 \%+$ Vitazyme & $23.75 \mathrm{ab}$ & $45.76 \mathrm{a}$ & $40.69 \mathrm{a}$ & $36.96 \mathrm{a}$ & 8.28 \\
\hline
\end{tabular}

Keterangan: Angka yang diikuti oleh huruf yang sama pada kolom yang sama tidak berbeda nyata pada taraf 0.05 berdasarkan uji Duncan

\section{Penelitian Lapang di Desa Cihideung Udik}

Kondisi tanaman padi pada awal tanam pada penelitian lapang di Desa Cihideung Udik dalam keadaan baik, akan tetapi pada umur 5 MST tanaman mulai menunjukkan gejala terkena penyakit tungro.

Hasil pengukuran tinggi dan penghitungan jumlah anakan memperlihatkan bahwa tidak terdapat perbedaan yang nyata antara perlakuan 100\% NPK dengan 50\%
NPK. Hasil ini menunjukkan bahwa pemupukan $100 \%$ NPK melebihi kebutuhan pupuk yang diperlukan tanaman dan takaran 50\% NPK saja sudah memenuhi kebutuhan tanaman. Akibatnya pengaruh pemberian Oligochitosan atau Biofertilizer tidak dapat dievaluasi (Tabel 9 dan Tabel 10). Hasil yang sama juga terjadi pada jumlah anakan produktif, bobot gabah kering panen (GKP) maupun bobot gabah kering giling GKG (Tabel 11).

Tabel 9. Pengaruh Oligochitosan dan Biofertilizer terhadap tinggi padi umur 2-8 MST di Desa Cihideung Udik, Kecamatan Ciampea, Bogor

\begin{tabular}{|c|c|c|c|c|}
\hline \multirow[b]{2}{*}{ Perlakuan } & \multicolumn{4}{|c|}{ Tinggi Tanaman } \\
\hline & $2 \mathrm{MST}$ & 4 MST & $6 \mathrm{MST}$ & $8 \mathrm{MST}$ \\
\hline & & & & \\
\hline NPK $100 \%$ & $26.98 \mathrm{~b}$ & 44.57 & 63.67 & 83.34 \\
\hline NPK 50\% & $29.03 \mathrm{ab}$ & 43.10 & 62.35 & 81.42 \\
\hline NPK $50 \%+$ Oligochitosan $(\mathrm{J})$ & $29.49 \mathrm{a}$ & 46.55 & 64.10 & 81.37 \\
\hline NPK $50 \%+$ Biofertilizer (A) & $27.24 \mathrm{ab}$ & 42.96 & 61.94 & 79.50 \\
\hline
\end{tabular}

Tabel 10. Pengaruh Oligochitosan dan Biofertilizer terhadap jumlah anakan padi per rumpun pada umur 2-8 MST di Desa Cihideung Udik, Kecamatan Ciampea, Bogor

\begin{tabular}{|c|c|c|c|c|}
\hline \multirow{2}{*}{ Perlakuan } & \multicolumn{4}{|c|}{ Jumlah Anakan } \\
\hline & 2 MST & $4 \mathrm{MST}$ & $6 \mathrm{MST}$ & $8 \mathrm{MST}$ \\
\hline & \multicolumn{4}{|c|}{$\ldots \ldots \ldots \ldots \ldots$ anakan rumpun $^{-1} \ldots \ldots \ldots \ldots$} \\
\hline NPK $100 \%$ & $1.73 b$ & 10.96 & 30.20 & 29.61 \\
\hline NPK $50 \%$ & $2.20 \mathrm{ab}$ & 13.41 & 29.15 & 28.99 \\
\hline NPK $50 \%+$ Oligochitosan $(\mathrm{J})$ & $2.43 \mathrm{a}$ & 13.75 & 29.83 & 28.84 \\
\hline NPK 50\% + Biofertilizer (A) & $1.86 \mathrm{~b}$ & 12.11 & 27.08 & 27.60 \\
\hline
\end{tabular}

Tabel 11. Pengaruh Oligochitosan dan Biofertilizer terhadap jumlah anakan produktif dan variabel produksi padi pada penelitian lapang di Desa Cihideung Udik, Kecamatan Ciampea, Bogor

\begin{tabular}{|c|c|c|c|c|c|}
\hline Perlakuan & $\begin{array}{c}\text { Jumlah Anakan } \\
\text { Produktif }\end{array}$ & Bobot GKP & Bobot GKG & $\begin{array}{c}\text { Bobot Gabah } \\
\text { Isi }\end{array}$ & $\begin{array}{l}\text { Gabah } \\
\text { Hampa }\end{array}$ \\
\hline & anakan rumpun $^{-1}$ & $\ldots \ldots$ & ton $\mathrm{ha}^{-1}$ & . & $\ldots \%$ \\
\hline NPK $100 \%$ & 16.68 & 4.36 & 3.60 & 2.91 & 19.44 \\
\hline NPK $50 \%$ & 15.99 & 4.52 & 3.89 & 3.27 & 16.20 \\
\hline NPK $50 \%+$ Oligochitosan $(\mathrm{J})$ & 14.71 & 3.92 & 3.00 & 2.43 & 19.34 \\
\hline NPK $50 \%+$ Biofertilizer (A) & 16.71 & 3.81 & 3.19 & 2.40 & 24.45 \\
\hline
\end{tabular}




\section{Penelitian Lapang di Desa Situ Gede}

Pada penelitian lapang di Desa Situ Gede, sama dengan apa yang terjadi dengan penelitian di Desa Cihideung Udik, takaran pupuk NPK 50\% sudah mencukupi untuk pertumbuhan dan produksi tanaman padi dan tidak berbeda nyata dengan pemupukan NPK $100 \%$ dosis. Di lokasi penelitian ini tanaman tidak terserang tungro. Tidak ada perbedaan yang nyata terhadap pertumbuhan maupun produksi padi antara perlakuan 50\% NPK dengan $100 \%$ NPK. Hal ini terlihat dari data pengamatan pertumbuhan tanaman (tinggi tanaman dan jumlah anakan) yang disajikan pada Tabel 12 dan data komponen produksi (jumlah anakan produktif, panjang malai, jumlah gabah per malai, jumlah gabah isi persentase gabah hampa, bobot 1,000 gabah (Tabel 13) maupun variabel produksi gabah kering panen (GKP) maupun bobot gabah kering giling (GKG) pada Tabel 14. Dengan demikian pengaruh penggunaan Oligochitosan atau Biofertilizer dalam memperbaiki pertumbuhan dan meningkatkan produksi padi di lapang dalam percobaan ini tidak dapat dievaluasi atau dinilai.

Tabel 12. Pengaruh Oligochitosan dan Biofertilizer terhadap tinggi dan jumlah anakan padi di Desa Situ Gede, Kecamatan Bogor Barat, Bogor

\begin{tabular}{|c|c|c|c|c|}
\hline \multirow{2}{*}{ Perlakuan } & \multicolumn{2}{|c|}{ Tinggi Tanaman } & \multicolumn{2}{|c|}{ Jumlah Anakan } \\
\hline & $4 \mathrm{MST}$ & $8 \mathrm{MST}$ & $4 \mathrm{MST}$ & $8 \mathrm{MST}$ \\
\hline & \multicolumn{2}{|c|}{$\ldots \ldots \ldots \mathrm{cm} \ldots \ldots$} & \multicolumn{2}{|c|}{$\ldots$ anakan rumpun ${ }^{-1} .}$. \\
\hline NPK $100 \%$ & 40.27 & 69.12 & 14.50 & 42.33 \\
\hline NPK $50 \%$ & 39.78 & 70.57 & 12.43 & 37.43 \\
\hline NPK $50 \%$ + Oligochitosan $(\mathrm{J})$ & 38.57 & 71.30 & 11.55 & 36.53 \\
\hline NPK $50 \%+$ Biofertilizer $(\mathrm{A})$ & 38.27 & 68.76 & 12.08 & 39.68 \\
\hline
\end{tabular}

Tabel 13. Pengaruh Oligochitosan dan Biofertilizer terhadap jumlah anakan produktif dan komponen hasil padi pada penelitian lapang di Desa Situ Gede, Kecamatan Bogor Barat, Bogor

\begin{tabular}{|c|c|c|c|c|c|c|}
\hline Perlakuan & $\begin{array}{l}\text { Jumlah Anakan } \\
\text { Produktif }\end{array}$ & $\begin{array}{l}\text { Panjang } \\
\text { Malai }\end{array}$ & $\begin{array}{c}\text { Jumlah } \\
\text { Gabah per } \\
\text { Malai }\end{array}$ & $\begin{array}{c}\text { Jumlah } \\
\text { Gabah Isi }\end{array}$ & $\begin{array}{l}\text { Gabah } \\
\text { Hampa }\end{array}$ & $\begin{array}{c}\text { Bobot } \\
1000 \\
\text { Butir }\end{array}$ \\
\hline & anakan rumpun $^{-1}$ & $\ldots \mathrm{cm} \ldots$ & ...... butir & . & $\ldots \%$. & gram \\
\hline NPK $100 \%$ & 16.13 & $23.51 \mathrm{ab}$ & 137.73 & 117.27 & 14.86 & $26.46 \mathrm{a}$ \\
\hline NPK $50 \%$ & 14.55 & $22.49 b$ & 124.07 & 105.43 & 15.01 & $26.19 \mathrm{a}$ \\
\hline NPK 50\% + Oligochitosan $(\mathrm{J})$ & 15.30 & $24.34 \mathrm{a}$ & 153.23 & 128.60 & 16.07 & $26.55 \mathrm{a}$ \\
\hline NPK $50 \%+$ Biofertilizer (A) & 15.20 & $22.94 b$ & 133.70 & 114.10 & 14.66 & $26.26 \mathrm{a}$ \\
\hline
\end{tabular}

Keterangan: Angka yang diikuti oleh huruf yang sama pada kolom yang sama tidak berbeda nyata pada taraf 0.05 berdasarkan uji Duncan

Tabel 14. Pengaruh Oligochitosan dan Biofertilizer terhadap variabel produksi padi pada penelitian lapang di Desa Situ Gede, Kecamatan Bogor Barat, Bogor

\begin{tabular}{|c|c|c|c|c|}
\hline Perlakuan & Bobot GKP & Bobot GKG & Bobot Gabah Isi & $\begin{array}{c}\text { Presentase } \\
\text { Gabah Hampa }\end{array}$ \\
\hline & $\ldots \ldots$ & ... ton ha ${ }^{-1}$. & $\ldots$ & $\ldots \% \ldots$ \\
\hline NPK $100 \%$ & 8.72 & 7.25 & 6.76 & 6.76 \\
\hline NPK $50 \%$ & 8.26 & 6.36 & 5.88 & 7.55 \\
\hline NPK $50 \%+$ Oligochitosan $(\mathrm{J})$ & 9.02 & 7.49 & 7.06 & 5.61 \\
\hline NPK $50 \%+$ Biofertilizer (A) & 8.72 & 6.94 & 6.47 & 6.63 \\
\hline
\end{tabular}

\section{SIMPULAN}

Pemberian Oligochitosan (Jepang), Oligochitosan BATAN, Vitazyme, dan Biofertilizer Azozo yang dikombinasikan dengan pemupukan NPK $50 \%$ pada penelitian pot nyata meningkatkan jumlah anakan per rumpun, jumlah anakan produktif, bobot gabah kering panen, bobot gabah kering giling, dan bobot gabah isi padi dibandingkan dengan pemupukan NPK 50\% saja dan menyamai pertumbuhan dan produksi pada perlakuan $100 \%$ NPK.

Penggunaan Oligochitosan, Vitazyme atau Biofertilizer mengurangi kebutuhan pupuk NPK yang diperlukan tanaman sebanyak 50\%.

\section{DAFTAR PUSTAKA}

Brahmaprakash, G.P. and K.S. Pramod. 2012. Biofertilizers for sustainability. Journal of the Indian Institute of Science, 92: 37-62.

Dzung, N.A. 2010. Enhancing crop production with chitosan and its derivatives. In Kim S. K. (Ed.). Chitin, Chitosan, Oligosaccharides and Their Derivatives. Biological Activities and Applications. New York (US): CRC Press. p. 619-629.

El-Tahany, A.M.M., R.M. Asma, M.A. Mona, and H.A. Aisha. 2012. Effect of chitosan doses and nitrogen sources on the growth, yield, and seed quality of cowpea. Australian Journal of Basic and Applied Sciences, 6: 115-121. 
Kannan T. and P. Ponmurugan. 2010. Response of paddy (Oryza sativa L.) varieties to Azospirillum brasiliense inoculation. Journal of Phytopatology, 2: 08-13.

Mawgoud, A.M.R.A., A.S. Tantawy, M.A. El-Nemr, and Y.N. Sassine. 2010. Growth and yield responses of strawberry plants to chitosan application. European Journal of Scientific Research, 39:161-168.

Nasahi, C. 2010. Peran mikroba dalam pertanian organik [Skripsi]. Bandung: Jurusan Hama dan Penyakit
Tumbuhan, Fakultas Pertanian, Universitas Padjajaran (Tidak dipublikasikan).

Rekso, G.T. 2005. Study on Irradiation of Chitosan for Growth Promotor of Red Chili (Capcinum annum) Plant. Jakarta: Centre for Application of Isotopes and Radiation Technology, National Nuclear Energy Agency.

Syltie, P.W. 1998. A Summary of Experiments Using Vitazyme Soil and Plant Biostimulant on Field and Horticultural Crops. Texas, Vital Earth Resources. 